\title{
The Occurrence of the Root-nodule Endophytes of Alnus glutinosa and Myrica gale in Soils
}

\author{
By C. RODRIGUEZ-BARRUECO* \\ Department of Botany, University of Glasgow \\ (Accepted for publication 6 December 1967) \\ SUMMARY
}

\begin{abstract}
Twenty-one soil samples from sites in West Scotland where alder (Alnus glutinosa) has not grown for many years were examined for the presence of the alder root-nodule endophyte by observing the production of nodules on test plants which were grown $(a)$ in water culture and their roots inoculated with an aqueous suspension of a soil sample, or $(b)$ in the soil itself. Twelve of the samples gave positive results, most of the remaining samples were at $\mathrm{pH}<4$. Ten samples from sites free from bog myrtle (Myrica gale) were similarly tested for the corresponding endophyte; 8 of these gave positive results. To explain these results it seems necessary to assume either that infective bodies of the endophyte can survive in soils for long periods, though not grow; or that the endophytes can grow saprophytically in soils and thus are not nearobligate symbionts.
\end{abstract}

\section{INTRODUCTION}

Alnus glutinosa (L.) Gaertn. (alder) and Myrica gale L. (bog myrtle) are the commonest examples in Britain of non-leguminous plants with nitrogen-fixing root nodules. The regular occurrence of root nodules on these species in the field raises the question of the source of the micro-organisms whose infection of the roots is necessary for nodulation to occur. On the basis of previous studies in this Department (Bond, 1963) the nodules of these two species are believed to be tenanted by distinct, specific organisms. Long experience here confirms that seed collected directly from the parent plants of these species does not carry the nodule organism, since plants grown from such seed in sterile media remain free from nodules. Under field conditions infection of young plants must occur from the soil.

In considering how the presence of the appropriate endophyte near a germinating seed could regularly arise, there is the difficulty that we have very little knowledge of the life history and growth requirements of these endophytes. The continued failure of attempts to isolate the endophytes of these and other non-leguminous plants into pure culture encourages the belief that they are near-obligate symbionts. One well-established feature, important in the present connexion, is that infective forms of the endophytes are present in the soil immediately around a nodulated plant. This is clear from the fact that one way of raising nodulated plants of these non-legumes is to sow seed in soil collected from near nodulated plants of the appropriate species. Experience in this laboratory has shown that this infectivity of habitat soils persists for at least several months in the absence of the host plant.

Three possible explanations of the regular presence of nodules in the field suggest themselves.

* Present address: Instituto de Edafologia, y Agrobiologia, Universidad de Salamanca, Spain. 
(I) Seed and endophyte may be disseminated from parent stands of host plants more or less simultaneously and by the same agents, of which wind would be the most important. Infective forms of the endophytes might be carried on soil dust or on leaves infected by contact with the soil.

(2) If the infective forms present around nodulated plants have considerable longevity, though they may be incapable of growth except in the vicinity of the host plant, then bearing in mind that prior to land drainage and clearance alder and bog myrtle were very widespread in Britain, a very broad distribution of the endophytes at the present time could be explained.

(3) If the belief, adopted in the two previous explanations, that the endophytes are near-obligate symbionts be set aside as unproved, then it may be supposed that they can grow saprophytically in soil and may have attained a wide distribution largely independent of that of the host plants, past or present.

It seemed possible that by a suitable examination of soil samples from sites where the host plants are not now growing, the choice between these suggestions could be narrowed down. Accordingly, soil samples were collected from various sites in the Glasgow region and tested for ability to induce nodulation in host seedlings growing in the greenhouse.

A difference between alder and bog myrtle is that while alder propagates by seed, under Scottish conditions bog myrtle chiefly spreads vegetatively by suckers and thus forms compact colonies. With alder the problem of the source of infection arises for every seedling except for those situated very close to the parent tree. With bog myrtle it is obviously possible that the soil near a colony becomes generally infected with the endophyte, for example as a result of water movement, so that roots of new suckers will be automatically infected. With bog myrtle it is chiefly at the initiation of a colony that the problem of the source of infection arises.

\section{METHODS}

General. Two methods were used: (I) The test plants were grown in water culture and inoculated by application to their roots of a water extract of a soil sample. This method has the advantages that standard and favourable conditions are provided for nodule development when the organism is present, while ready inspection of the root system is possible from day to day. (2) Young test plants were transplanted into the actual soil sample and allowed to grow there. It is possible that when the hyphae or resting bodies of the endophyte are present very sparsely in the soil, this might be a surer way of securing eventual contact between them and the roots. On the other hand, there is the risk that because of a very small $\mathrm{pH}$ value, or a richness in nitrogen, a soil might not be favourable to nodulation despite the presence of the endophyte. There is also the drawback with method (2) that the result of the experiment cannot be assessed before harvesting.

Collection of soil samples. Twenty-three soil samples were collected from sites within a 30-mile radius of Glasgow (Table I). Two samples (nos. 22, 23) were from sites where alder trees were present and four (nos. 6-9) from sites carrying bog myrtle bushes; these habitat soils were included as a test of the efficacy of the methods for detecting the endophytes. With these exceptions the sites were free from both host plants and have been so for at least the periods indicated in Table I. All samples were tested 
for the presence of the alder endophyte, but only a proportion for the bog myrtle endophyte.

In collecting the samples sterile metal cans of $500 \mathrm{ml}$. capacity were used as digging implements, being held by the base so as to obviate contamination by the hands. The samples were taken from the top Io- $15 \mathrm{~cm}$. of soil after removal of any surface litter. Immediately after collection the samples were transferred to new plastic bags. The samples were used 2-4 days after collection.

Table I. Details of soils used and results of tests of their capacity to induce nodules in Alnus glutinosa and Myrica gale

\begin{tabular}{|c|c|c|c|c|c|c|c|c|}
\hline \multirow{3}{*}{$\begin{array}{c}\text { Soil } \\
\text { sample } \\
\text { no. }\end{array}$} & \multirow{3}{*}{$\begin{array}{l}\text { Ordnance } \\
\text { map grid } \\
\text { reference }\end{array}$} & \multirow{3}{*}{$\begin{array}{c}\text { Present } \\
\text { description } \\
\text { of site }\end{array}$} & \multirow[b]{3}{*}{$\begin{array}{l}\text { Years of } \\
\text { such use }\end{array}$} & \multicolumn{5}{|c|}{ No. of test plants forming nodules } \\
\hline & & & & \multirow{2}{*}{$\begin{array}{c}\mathrm{pH} \\
\text { value of } \\
\text { sample } \\
\text { at col- } \\
\text { lection }\end{array}$} & \multicolumn{2}{|c|}{ Alnus glutinosa } & \multicolumn{2}{|c|}{ Myrica gale } \\
\hline & & & & & $\begin{array}{l}\text { Water } \\
\text { culture c }\end{array}$ & $\begin{array}{l}\text { Soil } \\
\text { ulture } †\end{array}$ & $\begin{array}{l}\text { Water } \\
\text { culture }\end{array}$ & $\begin{array}{c}\text { Soil } \\
\text { culture }\end{array}$ \\
\hline $\mathbf{I}$ & NS 550705 & \multirow{5}{*}{ Garden } & 50 & 6.6 & 0 & o & 一 & - \\
\hline 2 & NS 564679 & & 50 & $6 \cdot 7$ & o & o & 一 & - \\
\hline 3 & NS 546716 & & 100 & $7 \cdot 3$ & 0 & 4 & 一 & $\mathbf{I}$ \\
\hline 4 & NS 303828 & & 100 & $6 \cdot 5$ & 0 & I I & I & 2 \\
\hline 5 & NS 537674 & & 90 & $6 \cdot 8$ & 0 & 0 & 一 & 0 \\
\hline 6 & NN 537956) & \multirow{4}{*}{$\begin{array}{l}\text { Grouse moor, bog } \\
\text { myrtle present }\end{array}$} & $>100$ & $3 \cdot 8$ & 0 & 0 & 3 & I I \\
\hline 7 & NN 537956 & & $>100$ & $3 \cdot 8$ & o & o & - & - \\
\hline 8 & NN 533956 & & $>100$ & $3 \cdot 9$ & I & 0 & 一 & 6 \\
\hline 9 & NN 533956) & & 100 & $3 \cdot 9$ & 0 & 0 & 一 & 一 \\
\hline 10 & NN 534939 & \multirow{6}{*}{ Conifer plantation } & 20 & 4.4 & I & 0 & - & 12 \\
\hline I I & NN 535944 & & 20 & $3 \cdot 6$ & 0 & 0 & - & 0 \\
\hline 12 & $\mathrm{NN}_{499014}$ & & 38 & 3.5 & 0 & 0 & $\mathbf{I}$ & 0 \\
\hline 13 & NN 499014 & & 38 & 3.6 & o & 0 & 一 & 0 \\
\hline 14 & NN 547007 & & 32 & $6 \cdot 6$ & 4 & 9 & 0 & 3 \\
\hline 15 & NN 547007 & & 32 & $4^{\cdot I}$ & 7 & 6 & - & - \\
\hline 16 & $\mathrm{NN}_{532922}$ & \multirow{4}{*}{ Arable field } & $>50$ & $5 \cdot 8$ & 0 & 9 & - & 一 \\
\hline 17 & NN 656004 & & $>50$ & $6 \cdot 3$ & 0 & 4 & - & - \\
\hline 18 & NN 653954 & & $>50$ & $5 \cdot 7$ & I & 0 & - & - \\
\hline 19 & NN 649954 & & $>50$ & $5 \cdot 7$ & 0 & 3 & 0 & 2 \\
\hline 20 & NN 664993 & \multirow{2}{*}{ Pasture } & $>50$ & $6 \cdot I$ & 0 & 8 & - & - \\
\hline $2 I$ & NN 662955\} & & $>50$ & $6 \cdot I$ & 0 & IO & - & - \\
\hline 22 & NS 548758 & \multirow{2}{*}{$\begin{array}{l}\text { Amenity woodland, } \\
\text { alder present }\end{array}$} & 20 & $5 \cdot 7$ & 7 & 16 & 6 & 12 \\
\hline 23 & NS $561746 \int$ & & $\{>50$ & $3 \cdot 3$ & 7 & 0 & - & 3 \\
\hline
\end{tabular}

* In the water-culture method one jar containing seven plants of alder or six plants of bog myrtle was set up for each soil sample. In the soil-culture method two pots, each containing eight plants of alder or six plants of bog myrtle were set up for each soil sample; the total number of nodulated plants in the two pots together is given above.

$\dagger$ Statistical analysis of the data for the duplicate pots set up shows that the totals of plants forming nodules in any two soils should differ by at least 4 for significance at $P=0.05$ for alder, and by 5 for bog myrtle.

Germination of seed for test plants. Seed of the two host species was collected locally, and after storage at $2^{\circ}$ for 2 months was surface-sterilized by being shaken for $45 \mathrm{~min}$. in a $2 \%(\mathrm{w} / \mathrm{v})$ solution of calcium hypochlorite, followed by thorough washing with sterile water. The seed was then sown in Peralite (British Gypsum, Ltd., Cocklakes, Carlisle) moistened with nitrogen-free nutrient solution. The seedlings were used as indicated in the following section. 
Setting up of test plants. For the water-culture method Crone's culture solution (nitrogen-free formula) was used, adjusted to $\mathrm{pH} 4.8$ for alder and to $\mathrm{pH} 5.4$ for bog myrtle. Containers consisted of sterilized 21 . earthenware jars covered by teak squares previously dipped in molten paraffin wax, with seven holes for the plants. The seedlings were transplanted into water culture when two leaves had emerged, and $2.5 \mathrm{mg}$. ammonium nitrogen was then added to each jar to give slight support to the seedlings during the period normally required for nodulation. An inoculum was prepared from each of the soils by shaking $50 \mathrm{~g}$. with $50 \mathrm{ml}$. sterile water in a flask for $10 \mathrm{~min}$., standing the flask for $30 \mathrm{sec}$. and then filling a $20 \mathrm{ml}$. specimen tube with the supernatant suspension. The inoculation was effected by raising the tube so that the root systems of the plants in the teak top (now held in the hand) were immersed in succession, each for $3 \mathrm{sec}$. The inoculations were made a few days after transplanting, and from each soil sample one jar with seven alder plants was inoculated, while from a proportion of the soil samples one jar with six bog myrtle plants was similarly inoculated. The remainder of the soil-water mixture was used for $\mathrm{pH}$ determination by glass electrode. Some jars were left uninoculated to serve as controls, and were interspersed on the greenhouse bench among the inoculated jars. The plants were allowed to grow for 13 weeks after inoculation.

For the soil-culture method autoclaved clay pots ( $10 \mathrm{~cm}$. wide at the top, $9 \mathrm{~cm}$. deep) were used. Two pots were filled from each sample of soil for alder and, in some cases, another two for bog myrtle. Since many of the soil samples were from areas of low fertility, a fertilizer supplement was added to all pots to obviate the possibility of nodulation and plant growth being hindered by mineral deficiencies. This took the form of the addition to each pot of $0.14 \mathrm{~g}$. $\mathrm{CaHPO}_{4}+0 . \mathrm{I} \mathrm{g} . \mathrm{K}_{2} \mathrm{SO}_{4}$; test showed that this addition had negligible effect on the soil $\mathrm{pH}$ value. Eight seedlings of alder or six of bog myrtle were transplanted into each pot. Control pots containing autoclaved soil or in some cases Peralite were also set up, and were interspersed among the normal pots on the greenhouse bench. Distilled water was added to the pots at frequent intervals to restore them to their original weight. The plants were allowed to grow in the soils for II weeks.

\section{RESULTS}

\section{Alder}

No plant developed nodules in any of the eight uninoculated jars (total 56 plants) set up in water culture, nor in any of the Io control pots (total 80 plants) set up in soil culture. Thus accidental infection of plants by air-borne dust or by contamination from adjacent jars or pots did not affect the outcome of the experiment as a whole.

The results obtained are included in Table $\mathrm{I}$. The two soils from alder sites (nos. 22, 23) both induced nodulation of all the test plants in the water-culture method, after only 15 days from inoculation. Nodulation was also complete with no. 22 in the soilculture method, but did not occur with no. 23; this was very probably because the $\mathrm{pH}$ value of this soil, which had fallen considerably in recent years owing to deteriorating drainage, is now too low ( $\mathrm{pH}_{3.3}$ ) to permit nodulation. Ferguson \& Bond (1953) found that no nodules developed in alders in water culture in response to inoculation at $\mathrm{pH} 3 \cdot 3$, and only a few at $\mathrm{pH} 4 \cdot 2$.

With the remaining 2 I soils, all from sites where alders are not now growing, some degree of nodulation was shown in five samples by the water-culture method, although 
the speed of nodulation was much below that with the habitat soils. By the soil-culture method nine soils gave positive results, the greater sensitivity being presumably due to the consideration mentioned in discussing this method on page 190. The disparity between the two culture methods was sometimes quite large, e.g. in soils nos. 4, 20 and 21. Taking both methods together, evidence of the presence of the alder endophyte was obtained in 12 of the soils, comprising two from gardens, one from acid moorland, three from conifer plantations, four from arable fields, and two from pasture fields.

In the water-culture method, where the medium was nitrogen-free, the plants which formed nodules showed superior growth evidently as a result of nitrogen-fixation, since the degree of growth depended on the number and time of formation of nodules. With the soil-culture method, however, the incidence of nodules in the different soils could not be determined by inspection of the tops, since some of the soils contained sufficient combined nitrogen to sustain healthy growth for the duration of the experiment.

\section{Bog myrtle}

In the more limited tests for the bog myrtle endophyte, the two soils (nos. 6, 8) from sites where the host plant was present both showed evidence of the presence of the endophyte. Bond (1951) found that a few bog myrtle plants succeeded in forming

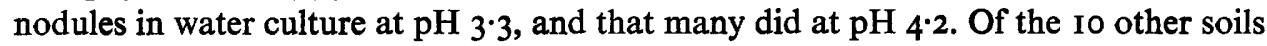
tested by one or both culture methods, eight showed evidence of the presence of the endophyte to various degrees. Again the soil-culture method gave more positive results than the water-culture method. As with alder, nodulated bog myrtle plants showed superior growth in the water-culture method, evidently as result of nitrogen-fixation. The same was true in the soil-culture method where fertility was sufficiently low.

\section{DISCUSSION}

It is evident that the alder and bog myrtle endophytes are fairly widely distributed in Scottish soils in which the host plants are not now growing. For alder it is probable that the results reported underestimate the prevalence of the endophyte, since in those soils of $\mathrm{pH}<4$ it is possible that the endophyte was present but was unable to induce nodulation in the soil-culture method because of the smallness of the $\mathrm{pH}$ value. It had been expected that in such circumstances the water-culture method would reveal the presence of the endophyte, but this method proved to be of low sensitivity.

The explanation of this widespread occurrence will now be considered in the light of the possibilities listed in the Introduction. With reference to the first of these the proximity of host plants to the sites where the endophytes proved to be present is important. A hilly terrain and limitation of access prevented a thorough examination of the area around a few of the sampling sites, but in the other instances it was established that the nearest host plants were too remote $(800 \mathrm{~m}$. or more away) for it to be supposed that the presence of the endophyte was due to its conveyance by wind or other factor from host stands.

The second suggested explanation supposes that infective parts of the endophyte can survive in the soil for long periods in the absence of the host. The data in Table I show that infective agents were present in soils which had not carried the host plants for at least 100 years. These were, however, garden soils, and there is a possibility that during that period the endophytes might have been introduced to the soils in added 
leaf-mould, peat, etc. The same could apply to the agricultural soils, but this objection does not apply to soil samples nos. I4 and 15, from Forestry Commission conifer plantations near Aberfoyle, nor to no. ro. Thus according to this explanation, infective power must have survived in the soil for at least 32 years, since there is no certainty that host plants were growing on the sites up to the time of their conversion to their present uses.

The ability of micro-organisms to survive for long periods under conditions which preclude active multiplication was reviewed by Sussman \& Halvorson (1966), who quoted instances of the survival of spores of various organisms including actinomycetes for periods of years. Jensen (196I) reported the survival of various bacteria, actinomycetes and fungi for IO-40 years when put into autoclaved air-dry soil; Sneath (1962) provided evidence of the persistence of bacteria in air-dry soil for at least 300 years, and of saprophytic actinomycetes for some 100 years. It appears possible that infective parts of the alder and bog myrtle endophytes might survive for long periods in the absence of host plants. If these infective parts originate in nodules it is possible that they are the so-called 'bacteroids' which persist in older parts of alder and bog myrtle nodule clusters from which other endophytic structures have disappeared.

The third possible explanation can also account for the findings of the present study but is open to objection on other evidence. The survey indicates that the usual reason why plants of alder and bog myrtle are regularly nodulated in the field in Scotland is that under existing conditions the soils already contain the requisite endophyte.

Pommer (1956) reported that pseudonodules can form in alder as a result of infection by common soil fungi, such as Cylindrocarpon radicicola or Penicillium albidum; such nodules were ephemeral and fixed no nitrogen. In the present study no such nodules were detected, and in all instances the presence of nodules was attended by obvious gain to the plant, except in a few cases in the soil-culture method where this could not be judged owing to the high fertility of the soil.

The author is grateful to the Fundación Juán March and to the Spanish Ministry of Education and Science for the award of scholarships which made this work possible. Gratitude is expressed to Professor P. W. Brian for extending the facilities of his Department, and to Professor G. Bond for his guidance in this investigation. Permission to collect soil samples from plantations was given by the Forestry Commission (Aberfoyle District).

\section{REFERENCES}

BoND, G. (I95I). The fixation of nitrogen associated with the root nodules of Myrica gale L., with special reference to its pH relation and ecological significance. Ann. Bot. I5, 447.

Bond, G. (1963). The root nodules of non-leguminous Angiosperms. In Symp. Soc. gen. Microbiol. 13. FERGuSON, T. P. \& BOND, G. (1953). Observations on the formation and function of the root nodules of Alnus glutinosa (L.) Gaertn. Ann. Bot. $17,175$.

JENSEN, H. L. (196I). Survival of Rhizobium meliloti in soil culture. Nature, Lond. 192, 682.

POMMER, E. H. (1956). Beiträge zur Anatomie und Biologie der Wurzelknöllchen von Alnus glutinosa Gaertn. Flora, Jena r43, 603.

SNEATH, P. H. A. (1962). Longevity of micro-organisms. Nature, Lond. r95, 643.

Sussman, A. \& Halvorson, H. O. (1966). Spores, their Dormancy and Germination. New York and London: Harper and Row. 